\title{
The Social Making of Educational Theory: Unraveling How to Understand the Content, Emergence, and Transformation of Educational Theory
}

\author{
Christian Sandbjerg Hansen \\ Trine Øland
}

\begin{abstract}
This article discusses the study of educational theories and ideas. Based on analyses of primarily the Danish scene, positing similarities with the other Nordic countries, we identify and investigate three main and today dominating approaches: a philosophical approach focusing on the content of the 'great' thinkers' ideas, their logical-coherence and/or moral-ethical value; a historical approach centering on individuals and their educational ideas expressed as views in a realistic and contextual story; and a Foucauldian approach which analyzes educational ideas and theories through their place in power-knowledge constellations. On the backcloth of analyses of the ontology and epistemology operating in these approaches we conclude that they all ignore the systematic study of the social context in which ideas and theories are conceived and we argue for a social space and social history approach as a way to fill out this epistemological vacuum.
\end{abstract}

Keywords

educational theory, epistemology, philosophy, history, new sociology of ideas

\section{Prologue}

In 1939 the Danish schoolteacher and -manager Thora Constantin Hansen (18671954) translated Maria Montessori's "Il segreto dell'infanzia” or "The Secret of Childhood" thus making the Montessorian ideas and theories of child rearing accessible for a larger audience in Denmark and especially for the pedagogical reform movement that formed in those days. The writings of Montessori had been translated earlier, a minor article appeared in 1915 and "Il metodo della pedagogia scientifica applicato alleducazione infantile nelle case dei bambini" or "The Montessori Method" was translated into Danish in 1917 - the same year that "The Montessori Society" [Dansk Montessori Selskab] in Denmark was founded in Thora Constantin Hansen's apartment. In the following decades Montessori as a distinct educational idea, theory and/or method, alongside Friedrich Fröbel, was discussed, put into circulation and canonized as, respectively, a mother and a father figure of preschool-kindergarten

Christian Sandbjerg Hansen is Assistant Professor of Educational Science at the Department of Education, Aarhus University, Denmark.

Email:csh@edu.au.dk

Trine Øland is Associate Professor of Educational Science at the Department of Media, Cognition and Communication, University of Copenhagen, Denmark.

Email: troeland@hum.ku.dk 
thought. This is hardly surprising: ever since the historical emergence of childhood a public and professional production and circulation of ideas concerning the child and its upbringing has increased and gained a wide-ranged territory. ${ }^{1}$ This points to the fact that educators do not restrict their practice to mere caring or educating; they talk about what they do as well; they give it a name; they call it a theory, a method or even a school of thought.

However, the less obvious question is how we can study and understand - theoretically and empirically - such manifestations of educational ideas or theories? The study of educational ideas and theories seems quite underdeveloped and undertheorized. Therefore, our aim is to discuss how one can theorize educational theories as an object for empirically based scientific scrutiny. ${ }^{2}$ The driving question for this article, then, becomes the following: how do different approaches study the content, emergence and transformation of certain educational ideas or theories, and what does it become possible to "see" and understand about educational ideas and theories using these theoretical approaches?

In order to answer this question we present and discuss concrete studies of educational ideas. Based on a wide reading of Nordic studies, it is possible to identify three main approaches: 1) a philosophical line of study of educational ideas especially represented by Danish philosophers Knud Grue-Sørensen and Sven Erik Nordenbo; 2) a historical line of study especially represented by Danish historian Ning de Coninck-Smith; and 3) an approach that takes the French historian of ideas, Michel Foucault, as main point of reference represented primarily by the Swede, Kenneth Hultqvist. To simplify and organize the article and its arguments, we treat these studies as representatives of general - or ideal-typical - approaches, and so we aim to highlight the distinct characteristics of each stance.

Our aim, then, is not to show how these studies came about in specific historical contexts and social and institutional settings, but to characterize and discuss them theoretically, i.e. focusing on their scientific and analytical characteristics. Even though the approaches declare that they, for example, do not use explicit theory, and do not construct their objects theoretically, we nevertheless investigate the assumptions that seem to be involved in the approach. Though these three approaches are the main and dominating approaches in the study of educational theory and ideas today, they rarely engage in discussions with one another. ${ }^{3}$ Therefore, an analysis of their relations will qualify discussions across approaches. Further, we want to make way for another - fourth - yet marginalized approach: the socio-historical approach.

1 See e.g. Hugh Cunningham, Children and Childhood in Western Society since 1500 (Harlow \& New York: Pearson Longman, 2005).

2 This implies that "theory" is both part of the article's way of investigating ("theorizing") and part of what the article is investigating ("educational theory and idea" and the ways in which this has been studied). Further, the definition of "theory" thus becomes an empirical question: what is at a given moment in time put forth, accepted and recognized as an educational idea or theory? Hence we will refer to "ideas and theories" continuously in order to mark that the difference between the two is an empirical matter.

3 Johan Prytz, Speaking of Geometry: A Study of Geometry Textbooks and Literature on Geometry Instruction for Elementary and Lower Secondary Levels in Sweden, 1905-1962, With a Special Focus on Professional Debates (Uppsala: Uppsala University, 2007) would be an exception on the Nordic scene; Rita Hofstetter and Bernhard Schneuwly, "Institutionalisation of Educational Sciences and the Dynamics of their Development," European Educational Research Journal 1 (2002), 3-26, on the continental. 
Thus, on the backcloth of an analysis of the three main positions on the study of educational ideas, we seek to demonstrate the specific characteristics and epistemological advantages of a socio-historical stance inspired by the new sociology of knowledge in general and the sociology of Pierre Bourdieu specifically. ${ }^{4}$ Consequently, we identify that all of the three former theories ignore the systematic study (empirical as well as theoretical) of the social context, the institutional perimeters and the structured trajectories of the agents that produce and consume ideas and theories. In closing the article we suggest a Bourdieu-inspired social space and social history approach oriented towards analysis of the mechanisms, channels, conditions and processes through which educational theories gain legitimacy and territory, becoming if not dominant, then significant.

\section{Three customary approaches}

Based on a wide reading across the Danish research scene, the following three approaches have been constructed analytically as ideal-typical approaches. They are portrayed using examples in order to illustrate the general properties of the approaches. As the approaches are different, the examples will be different and thus the three sub-sections are different in form and argument. However, in each sub-section we first describe the approach in general terms. Second, we show the properties of the approach in detail using examples. In order to avoid the creation of easily shotdown straw-men we make a relatively close reading of dominant and influential works representative of the diversity of the (Danish) educational research field. ${ }^{5}$

\section{The development of categories of thought - educational theory understood by philosophy}

Historically, philosophy has had a great impact on the systematization of educational thinking and has heavily influenced the study of education and educational ideas and theories on the Danish scene. The philosophical approach focuses on the history of educational ideas in questions of content, consistency and logic. ${ }^{6}$ The first

4 To a sociologist this could seem as a predictable and maybe even unnecessary theoretical argument that should have been demonstrated by way of empirical comparison. However, presenting such efforts among historians and philosophers make it clear that these arguments are far from self-evident outside the sociological mind. In other words, in order to engage in both empirical and theoretical discussions across the educational science field, we have found it necessary to do a theoretical cleaning, that is, to do a conceptual ground work before we enter the empirical world. Reversely, one could argue that the digging into the archives is far from self-evident and straightforward to the sociologist who rarely uses such materials. Our objective is not to discard the legitimacy of the three main positions and establish some kind of all-embracing and superior sociology, but to stimulate discussion across positions and better the argument of all.

5 One might object that the three positions qua their differences make comparison impossible. However, this seems to be a premise for all comparisons that strive to highlight variations and differences.

6 Other versions, although very different versions, of this approach are Gerd Christensen, Individ og disciplinering: Det poedagogiske subjekts historie (Frederiksberg: Samfundslitteratur, 2008); Thomas Aastrup Rømer, At loere noget i en verden uden geloender: En kritisk diskussion af nyere loeringsteori (København: Danmarks Pædagogiske Universitets Forlag, 2005); Uddannelse i speending: Åbenhjertighedens, påmindelsens og tilsynekomstens predagogik (Århus: Klim, 2010), Jesper Eckhardt Larsen, J.N. Madvigs dannelsestanker: En kritisk humanist i den danske romantik (København: Museum Tusculanum, 2002); Thyge Winther-Jensen, Undervisning og menneskesyn hos Platon, Comenius, Rousseau og Dewey (København: Akademisk Forlag, 2004); Alexander von Oettingen, Pcedagogisk filosofi som reflekteret omgang med poedagogiske antinomier: Perspektivering af K. Grue-Sørensens 
professor in educational science in Denmark, the philosopher Knud Grue-Sørensen, distinguished the history of manners (upbringing) from the history of ideas, paralleling the distinction between educational history of reality versus educational history of ideas. ${ }^{7}$ Although Grue-Sørensen argues for interplay between the two forms of history, he primarily writes educational history of ideas in terms of describing what he thinks of as guiding ideas behind educational practice and educational thinking and theory in different time periods, chronologically portrayed as a history of the development of ideas. The text in his work on educational history is organized as "sequences of kings" replacing one another, driven by a main interest in the character and development of ideas, often presented as related to the personality of the thinker. For example, on the sudden emergence and diffusion of Pestalozzi's "theory and method", Grue-Sørensen writes the following: ${ }^{8}$

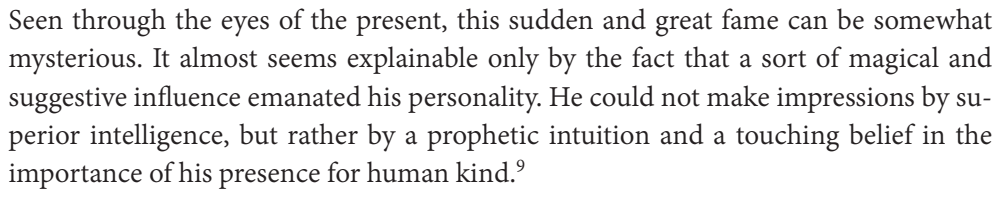

Sven Erik Nordenbo, another Danish educational philosopher, further describes the emergence, specialization and institutionalization of educational science as an internal philosophical accomplishment. ${ }^{10}$ His point of departure is to clarify the theory of science used to study historical development, presenting two alternatives: a historical "realism" and a historical "constructivism"."1

For Nordenbo, "realism" defines historical accounts about the past and is characterized as both common sense realism and traditional historiography using compilation of remains, narratives and reports - and source criticism as a technique to evaluate the strength of the sources. Nordenbo rejects this stance using an argument drawn from historical skepticism that it is epistemologically impossible to determine a correlation between the sources and the past, and therefore socio-historical studies of the past are impossible. ${ }^{12}$ As we will show later in this article, this argument does not rule out the possibility that the past existed and works its ways in the present, neither that the past can be (re-)constructed on the basis of specific sources and sci-

filosofiske poedagogik (Århus: Klim, 2006); Peter Ø. Andersen, "Pædagogik og pædagogiske teorier i Danmark fra 1960," in Klassisk og moderne poedagogisk teori, eds. Peter $\emptyset$. Andersen, Tomas Ellegaard and Lars Jakob Muschinsky, 54-96 (København: Hans Reitzels forlag, 2007). For example, Andersen (2007) can be read as a combination of the history of ideas/philosophy approach and the Foucauldian approach; the same goes for Christensen (2008); while Larsen (2002) can be read as a combination of elements from the philosophy approach and the historian line of thought.

7 Knud Grue-Sørensen, Opdragelsens historie I-III (København: Gyldendels pædagogiske bibliotek, 1959), i, 9-11.

8 All translations from Danish to English are ours.

9 Grue-Sørensen (1959) II, 197.

10 Sven Erik Nordenbo, Bidrag til den danske poedagogiks historie (København: Museum Tusculanum, 1984), 135-7.

11 Ibid., $137-153$.

12 Ibid., 143. 
entific work. ${ }^{13}$ It only rules out that the relation between the past and the present is simply a matter of logic and consistency.

"Constructivism", on the other hand, Nordenbo states, defines historical accounts which construct a historical past using historical data, accomplished by the historians' interpretive activity in the present which is considered constitutive of the research process and the historical account. ${ }^{14}$ Nordenbo states that the correlation problem thus is dissolved, and therefore he argues for historical constructivism. Historical accounts are understood exclusively as constituted by their own logic and based on the researchers' ability to understand and interpret the sources so that a construction can be made. Such an approach rules out the idea of a scientific and historical object with its own logic to be understood, regardless of the researchers' immediate frame of mind and interpretation. ${ }^{15}$

To sum up, according to the philosophical approach educational ideas or theories are exclusively about the development of categories of thought performed by educational philosophers and thinkers. The study of educational ideas and theories are defined as a narrow humanistic discipline, using history, philosophy and psychology, which matches a historical account about the goal-means scheme: educational goals are elucidated by educational philosophy; educational means are reflected using both history and psychology. To Nordenbo only such a definition makes it possible to deal with what he terms educational reflection [pædagogisk refleksion], i.e. problems of educational arguments, justifications and values connected to educational activity and human action. ${ }^{16}$ According to Nordenbo, social science and social history approaches in educational science is a threatening "dehumanizing" project that lowers educational ideas to ideas about investment: economy thinking and technology. Nordenbo seems to read the social science and social history tendency as normative accounts connected to Marxism. As we will elucidate later, a social science and social history approach does not necessarily involve normative economism, etc. Thus, we consider this sort of humanistic and moral panic characterization of social science and social history a straw-man which seems to make it acceptable - or even heroic - not to be bothered by social science and social history approaches.

\section{Individuals and their ideas in historical context - educational theory under- stood by the science of history}

The second approach we will examine is historical. The historical line of thought studies ideas as well, often in terms of views, i.e. changing views on the child, childhood, the school or the school building. Representatives of this approach study the views of different individuals, establishments of networks and relations between individuals, and developments around specific events and "ruptures". Furthermore, a broader historical context is included in the writing of this type of educational history. Com-

13 Staf Callewaert, "Hvordan skal man skrive den danske pædagogiks historie?" Tidsskrift for Nordisk forening for poedagogisk forskning 3-4, (1984), 76-7.

14 Nordenbo (1984), 146.

15 Parallel to the discussion of realism versus constructivism, writing his specific version of a historiography of educational science in Denmark, Nordenbo establishes a distinction between an externalistic social history approach and an internalistic history of categories (ideas) approach.

16 Sven Erik Nordenbo, "Uddannelsesforskning - pædagogik, en humanistisk disciplin", Nyt om uddannelsesforskning 1, no. 3 (1981), 3-6. 
pared to the former and the following approach, the contextualization seems to take place at the expense of detailed descriptions of the educational ideas that are studied. Instead, the views often appear as examples of political-ideological stances which circulate in the broader historical context.

To demonstrate the characteristics of this stance, we investigate some of Danish historian Ning de Coninck-Smith's works. ${ }^{17}$ She refers to anthropological history when describing how she writes the history of childhood or school history, breaking with both the philosophical line of study and Marxist views of history as a totality. Instead, the agent is put in front of the writing of history. Anthropological history is a term used to cover different upcoming disciplines in the science of history which adheres to: new cultural history, micro history and history of everyday life. ${ }^{18}$ In particular, the focus is on micro practices and cultural significance, which is extracted from experiences written down by individuals - often represented in sources such as travel reports and letters. For example de Coninck-Smith has studied the progressive school pedagogues, Anne Marie Nørvig and Sofie Rifbjerg's trips to USA before and after WWII, and investigated how these progressive school pedagogues were inspired in the American context which changed their views etc. ${ }^{19}$ For example de Coninck-Smith writes:

In 1946 the Danish educational reformer and child psychologist, Sofie Rifbjerg (18861991) travelled for six months to the USA. The aim of her trip was to study American developmental and child psychology. Her interest in the USA had presumably been aroused by the international educational reform movement that arose between the wars. $^{20}$

Then it is described that Rifbjerg visited different experimental schools and who she met. It is even assumed whom she met. After introducing an Australian-born psychologist (Landreth) who appeared in the American context, it is stated:

\footnotetext{
We do not know if these two women ever met, but in the interest of the remainder of the story we assume they did. Presumably they soon found themselves on the same wavelength, for Sofie Rifbjerg had to some extent the same educational models as Professor Landreth. Children were to have good conditions for growing up and freedom to develop at their own pace. ${ }^{21}$
}

17 Other variations of this approach are Christian Ydesen, The Rise of High-Stakes Educational Testing in Denmark (1920-1970) (Frankfurt: Peter Lang, 2011); Anne Løkke, Døden i barndommen: Spæedbørnsdødelighed og moderniseringsprocesser i Danmark 1880 til 1920 (København: Gyldendal, 1998); Karin Lützen, Byen tommes: Kernefamilie, sociale reformer og velgørendehed $i$ 180otallets København (København: Hans Reitzels forlag, 1998), who, although they are different, analytically can be categorized as affiliated with this approach as historians. Ydesen, for example, unlike many historians, explicitly use theory in his writings.

18 Ning de Coninck-Smith, For barnets skyld: Byen, skolen og barndommen 1880-1914 (København: Gyldendal, 2000), 27, n17.

19 Ning de Coninck-Smith, "Det demokratiske børneopdragelsesprogram. Anne Marie Nørvig om børn, forældre og familie i USA og Danmark i 1930-1955," in Samfundets børn, eds. Mads Hermansen and Arne Poulsen (Århus: Klim, 2002); Ning de Coninck-Smith, "The Panopticon of Childhood: Harold E. Jones Child Study Center, Berkeley, California, 1946-1960," Paedagogica Historica 41, no. 4-5 (2005), 495-506.

20 de Coninck-Smith (2005), 497.

21 Ibid., 498. 
The ideas studied here are not distinct, but ideas as "movements" in a wide sense. A story is told about the two and their similar views in quite rounded and straightforward categories. Thus, here the historian is a competent and clever storyteller too, caring about "the interest of the story", knowing how to tell a story, which is generally understood in cultural ideological terms, based on interpretations of "presumable" motives and relations.

Anne Marie Nørvig's trip to the USA is interpreted in both a biographical and cultural context as an element of the dissemination of "new ideals" about "family, parenting and childhood" ${ }^{22}$ Nørvigs' thinking is also described as inspired by other individuals' thinking, e.g. the Swedish social psychologist, Alva Myrdal and her views on parenting. de Coninck-Smith interprets "the project" in general as a project of reason to combat habit and tradition. ${ }^{23}$ These are very broad oppositions not specific to educational debate, but belonging to a more general debate of cultural politics.

In another study, de Coninck-Smith has investigated the way in which "biographies" of individual innovators (architects) intersect and makes up a network referring to the so-called spatial turn and methodology in historiography. ${ }^{24}$ The focus is on the motives and intentions of individuals, and the relations and interactions between individual British and Danish architects and associations, the exposure of courses of events, and relations between local geography and "developments and discussions on the national and international scene" are revealed. ${ }^{25}$ In this piece it is explicitly stated that the intention is to "inscribe the architecture in a broader social and cultural historical narrative and, more specifically for educational architecture in a broader social and cultural historical narrative of childhood and education". ${ }^{26}$ Thus, the historical context becomes "a narrative" which is added in order to interpret the ideas and intentions in a "greater" context. In other texts it is named a period. For example "a century": "The right to play was a product of the 19th century's bourgeois, masculine individualism with demands of respect of the single individual and with the independent, rationally thinking and acting male as ideal" ${ }^{27}$.

One way or the other, the historical stance can be characterized as a historical-hermeneutical approach focusing on the agents of history and adding interpretive power from a broader historical context and well known narratives and oppositions of cultural politics. In different ways the historian immerses herself like a phenomenologist in the historical sources, the courses of events and the broad historical contexts in order to compose educational stories about changing ideas and views and how they came about, interpreted and related to stories that circulate already in the broad cultural context.

22 de Coninck-Smith (2002), 15.

23 Ibid., 21.

24 Ning de Coninck-Smith, "Danish and British Architects at Work: A Micro-Study of Architectural Encounters After the Second World War," History of Education 39, no. 6 (2010), 713-730, cf. Ydesen (2011) as well.

25 de Coninck-Smith (2010), 713.

26 Ibid., 714.

27 Ning de Coninck-Smith, "Legeteorier, leg og legepladser," Tidsskrift for børne- og ungdomskultur 30, (1993), 22. 


\section{Categories and ideas as productive systems of reason and power - educatio- nal theory understood by Foucauldian studies ${ }^{28}$}

The third approach we will examine is an approach inspired by Foucault and often displayed as governmentality-studies, but also for example as genealogies. Generally speaking, this approach focuses on how different forms of knowledge relate to forms of power and subjectivity in specific historical contexts and periods. Here educational ideas are studied not through questions of true or false or through concrete agents' motives and deeper meanings, but through their place and mode of functioning within a power-knowledge constellation. Broadly speaking, these studies analyze how pedagogical ideas are made possible and recognizable and how they produce different ways of being object and subject in pedagogical matters. Referring to Foucault's understanding of genealogy and archaeology ${ }^{29}$ the historical ambitions of these studies are formulated through a so-called history of the present, that is, a history oriented towards a destabilization of the present power-knowledge constellations. ${ }^{30}$

Kenneth Hultqvist's genealogy of the discourse on modern childhood is a prominent example of such a "history of the present" and can serve as a starting point for a discussion of the principle characteristics of Foucauldian studies of educational ideas. ${ }^{31}$ Through a reading of canonical educational texts on the one hand, and different "state" or "governmental" papers and programs on the other, Hultqvist reconstructs "what has actually been said" about the child, how it has been said, and which discourses have been used. Thus analyzing the lines of demarcation by which some things can be said about children with the aid of certain discourses, while other things become unmentionable, even unthinkable, Hultqvist shows how a Fröbelarian discourse on the child gradually became not replaced by, but rearranged within the discourse of, developmental psychology and thereby part of a new construction of the child and a new form of governing:

28 The reception of Foucault's work is complex and diverse and could easily fill up an article in itself. For the purpose of clarity, the nuances and differences of these interpretations are left out of this article.

29 Michel Foucault, "Nietzche, Genealogy, History," in The Foucault Reader, ed. Paul Rabinow (New York: Pantheon Books, 1984), and Michel Foucault, The Archaeology of Knowledge (London: Routledge, 2002 [org. 1969]).

30 Kenneth Hultqvist and Kenneth Petersson, "Nutidshistoria: Några inledande utgångspunkter," in Foucault: Namnet på en modern vetenskaplig och filosofisk problematik, eds. Kenneth Hultqvist and Kenneth Petersson (Stockholm: HLS Förlag, 1995).

31 See Kenneth Hultqvist, Förskolebarnet: En konstruktion för gemenskapen och den individuelle frigörelsen (Stockholm: Symposion Bokförlag, 1990). Other representatives are Maja Plum, "The Emergence of the Analytical Method in Early Childhood Education," The International Journal of Qualitative Studies in Education 25, no. 5 (2012), 645-663; John B. Krejsler, "Quality Reform and 'the Learning Pre-School Child' in the Making: Potential Implications for Danish Pre-School Teachers," Nordic Studies in Education 32, no. 2 (2012), 98-113; Kaspar Villadsen, Det sociale arbejdes genealogi: Om kampen for at gøre fattige og udstødte til frie mennesker (København: Hans Reitzels forlag, 2004); Carsten Bendixen, Psykologiske teorier om intelligens og folkeskolens elevdifferentiering: En analyse af transformation af psykologiske teorier om intelligens som baggrund for skolepsykologiske og paedagogiske afgørelser vedrørende elevdifferentiering i det 20. Århundredes folkeskole (Roskilde: Roskilde Universitetscenter, 2006); Bjørn Hamre, Potentialitet og optimering: Problemforståelser og optimering i skolen (Aarhus: Aarhus Universitet, 2012), and Graham Burchell, Colin Gordon and Peter Miller, eds., The Foucault Effect: Studies in Governmentality (Chicago: University of Chicago Press, 1991) as the key reference in globo. 
With the aid of F.W. Fröbel's philosophy and pedagogical thinking, a 'child' is produced that, similar to constructions within modern psychological theory, is based on a shift of norm-establishment from the fully developed adult to the child. The child appears as the incarnation of the new era, of the new human being, and of a more civilized community. ${ }^{32}$

Thus, Foucauldian studies of the history of the present involve "[...] a historicizing that is not concerned with causal or origin narratives but with the productive qualities of power and with a notion of history in which multiple trajectories overlap to form a single plane rather than a history of origins". ${ }^{33}$ These studies of the historical and social traveling of educational ideas and theories attempt to write a history that is "not straightforward, involves multiple transactions and trajectories, and entails intense struggles." 34 Thus, following Foucault, these studies read ideas as monuments, that is, as rules of reason and reasoning and not as descriptions of a certain phenomenon or affair or as interpretations of reality made by concrete individuals. The main interest for these studies seems to be not the reasons for or causes to the historical changing of ideas, but rather how ideas merge or transform and thus constitute new regimes of truth, new power-knowledge relationships and new forms of subjectivity. The American scholar Thomas Popkewitz, who has greatly influenced the Nordic readings of Foucault, shows how, in contemporary educational reform discourses, Dewey and Vygotsky are reread as part of changes in "governing systems of the self" in a manner that differs "from those current at the turn of the century". ${ }^{35}$ The two different rules of reason are both a form of "governing the soul", that is, the disciplinary processes by which individual desires, affects, and bodily practices are made the focus of scrutiny and administration, and the object of change, but contemporary constructivism "remakes the problem of inclusion/exclusion through its focus on seemingly universal dispositions and the problem-solving capabilities of the child" ${ }^{36}$ Thus, there is no idea "outside" the system of relations that constitutes it as such, as this approach does not operate with "inside" versus "outside"; ideas are not just logical principles, they are also governing principles, forms of power that "produce systems of exclusions as well as inclusions". ${ }^{37}$ Note that systems of inclusion and exclusion in governmentality studies such as Popkewitz's are systems or reason which carries principles of observation and normalization. Although Popkewitz somehow relates these systems to what he terms questions of inequality, it is important to note that the systems of reasons are epistemological matters and not sociological matters. ${ }^{38}$

32 Hultqvist (1990), 286.

33 Thomas Popkewitz and Marianne Bloch, "Administering Freedom: A History of the Present - Rescuing the Parent to Rescue the Child for Society," in Governing the Child in the New Millenium, eds. Kenneth Hultqvist and Gunilla Dahlberg (London \& New York: Routledge, 2001), 111-4.

34 Thomas Popkewitz, "Dewey, Vygotsky, and the Social Administration of the Individual: Constructivist Pedagogy as Systems of Ideas in Historical Spaces," Amercian Educational Research Journal 35, no. 4 (1998a), 536.

35 Ibid., 547.

36 Ibid., 560 .

37 Ibid., 560 .

38 Thomas Popkewitz, Struggling for the Soul: The Politics of Schooling and the Construction of the Teacher (New York: Teachers College Press, Colombia University, 1998), 2. 


\section{Summa: what are the differences and similarities between the three app- roaches?}

The relations between the three different approaches revolve around two basic questions according to this article's way of investigating theoretically: what is the implicit or explicit ontology and epistemology operating, and how are "ideas/theories" conceived (defined and studied) within the different approaches?

\section{Realism vs. constructivism; empiricism vs. rationalism}

The main difference between the philosophy approach and the Foucauldian approach on the one side and the historical-hermeneutical approach on the other is characterized by the ontological and epistemological differences between constructivism and realism, and between empiricism and rationalism. Traditional history's injunction of realism, causality and context is rejected by Foucauldian studies for a constructivist priority to the discursive. While the historical approach seeks out a non-discursive context in which educational ideas and theories are articulated, the Foucauldian approach, according to the radicalism of their constructivism, treat everything as discourse, and the philosophical approach more or less pragmatically argues for the autonomy of the ideas, i.e. versus "the real". This is not to say that "real" events and incidents do not appear in these writings; they certainly do, but they merely play the role as descriptive elements or dramatical figures rather than analytical objects. Thus, contrary to "traditional historiography", the Foucauldian studies (and Nordenbo, but not Grue-Sørensen) hold the epistemological stance that history does not exist outside the research practice. Instead, they view history as an effect of the historian's research practice. This stance does not imply that they think that "things" did not happen in the past, but rather that they highlight that the past cannot by automatism bear witness of the truth of its own meaning or significance. ${ }^{39}$ On the other hand, from the perspective of the historical approach, constructivism and Foucauldian inspiration has been invoked under banners such as "new cultural history", "social history" or "micro-history". ${ }^{40}$ In concrete studies this influence has first and foremost to do with content in that the historians take up themes similar to Foucault - the prison, the mad, discipline, power, etc. When it comes down to the practice of historical analyzes, though, often the Rankean dictum of "wie es eigentlich gewesen ist" still operates as an epistemological doxa. ${ }^{41}$ E.g. cultural historian Karin Lützen writes the following in a review of Foucauldian sociologist Kaspar Villadsen's book on the genealogy of social work:

39 Hultqvist and Petersson (1995), 24.

40 Dorthe Gert Simonsen, Tegnets tid (København: Museum Tusculanum, 2003); Lynn Hunt, The New Cultural History (Berkeley, Los Angeles \& London: University of California Press, 1989); Paula S. Fass, "Cultural History/ Social History: Some Reflections on a Continuing Dialogue," Journal of Social History 37, no. 1 (2003), 39-46; Christophe Charle, "Contemporary French Social History: Crisis or Hidden Renewal?" Journal of Social History 37, no. 1 (2003), 57-68.

41 Gerard Noiriel, "Foucault and History: The Lessons of a Disillusion," The Journal of Modern History 66, no. 3 (1994), 547-568; Reinhart Koselleck, The Practice of Conceptual History (Stanford: Stanford University Press, 2002), 1-19; Georg Iggers, Historiography in the Twentieth Century: From Scientific Objectivity to the Postmodern Challenge (Middletown: Wesleyan University Press, 2005). Some historians might object to such a view, arguing that historical accounts are more or less coherent and substantiated constructions. 
As good as all of the source materials that Kaspar Villadsen use are debates, suggestions, in short wishes of how things should be or criticism of how it is. On the background of this material, then, Kasper Villadsen makes claims of how things 'actually' were, but for that he has no evidence. He does not go through, e.g., the different laws, that is, those initiatives that actually were put in motion, but he concludes solely from the discussions. ${ }^{42}$

Off course, Villadsen has no interest in the actual behavior or lived life and he does not intend to "reach the real". Instead he reads the sources in their positive posture as parts of a truth regime, not in the search of their "hidden" or "deeper" meaning. For example, Foucault stresses this in the following way:

If I had wanted to describe 'real life' in the prisons, I indeed wouldn't have gone to Bentham. But the fact that this real life isn't the same thing as the theoreticians' schemes doesn't entail that these schemes are therefore utopian, imaginary, and so on. One could only think this if one had a very impoverished notion of the real. ${ }^{43}$

Instead, to Foucault, the interest is to analyze how "programs induce a whole series of effects in the real [...] as the distinction between true and false implicit in the ways men 'direct', 'govern' and 'conduct' themselves and others" 44.

To sum up, it is fair to say that it seems as if constructivism liberates both the philosophical and the Foucauldian approach from the meticulous tracing of archives and clues and provides a dexterity and sensibility towards the internalistic structures of the ideas and theories in themselves. So, philosophical and Foucauldian studies have drawn attention to the internal structure of ideas and theories, whereas historical studies have uncovered the socio-political context in which educational ideas and theories are articulated by concrete historical individuals. In this respect, however, the difference between Foucauldian studies and the philosophical approaches lie in the former's attempt to link educational ideas not to questions of inner coherency, truth, or moral value, but to rationalities of government, that is, to the interplay of knowledge, power and subjectivity. ${ }^{45}$

Thus, the relation between Foucauldian researchers and historians are ambiguous. In other words, the science of history seems to somewhat resist the empirical and theoretical consequences of a radical constructivist approach. ${ }^{46}$ While the philosophical approach that has Nordenbo as key example is seeking the inner logic and coherence of the ideas within a constructivist perspective that is rarely rationalistic in the sense that it explicitly theoretically constructs an object to be studied. For the philosopher, a theoretical discussion is a matter of analyzing the different arguments

42 Karin Lützen, "Kaspar Villadsen: Det sociale arbejdes genealogi: Om kampen for at gøre fattige og udstødte til frie mennesker," Dansk Sociologi 3 (2005), 107-9, citation p. 109.

43 Michel Foucault, "Questions of Method," in Power: Essential Works of Foucault 1954-1984, Vol. 3, ed. James D. Faubion (New York: The New Press, 2000 [org. 1980]), 232.

44 Ibid., 233.

45 Kenneth Hultqvist, "Changing Rationale for Governing the Child: A Historical Perspective on the Emergence of the Psychological Child in the Context of Preschool - Notes on a Study in Progress," Childhood 4, no. 4 (1997), 406.

46 Edward H. Carr, What is History? (London: Penguin Books, 1990 [org. 1961]), 12; Iggers (2005), 150. 
for or against a certain educational theory in terms of its moral-ethical value or logical-conceptual coherence - not a discussion of how a given theory is to be grasped theoretically. While the Foucauldian approach sets an explicitly formulated and discussed arsenal of notions/concepts in motion - power-knowledge-subject, past-present, document-monument, etc. - the philosophical remains somewhat blind for that aspect of their own perspective. The same goes for the historical approach in that it remains somewhat unaware of (or uninterested in discussing) how theoretical concepts not just inform the frame of reference of a research program, but actively guide the practical-empirical workings through the archives as well as the analytical outcome. Using theory analytically throughout the study is thus different from using theory and concepts to inform the overall frame of reference in the beginning of the study or to interpret the results in the end. Contrary to this empiricist philosophy, the Foucauldian approach, conceived within a rationalistic philosophy (going back from Foucault to Canguilheim and Bachelard to Descartes), holds the stance that the past not only exists to be uncovered in its objective reality, but that as a scientific object, it must be constructed as such.

\section{Ideas conceived}

The second, main difference that defines the relations between the three approaches addresses how the educational ideas as object of scientific scrutiny is defined and investigated, including the sources used in the analysis. On the one hand we find the philosophical approach that studies ideas in history alongside the historical-hermeneutical approach that studies men and women of history and their ideas in a historical context. These two approaches unite in that their object is historical, which set them apart from the Foucauldian approach that does not take history as an object sui generis, but, rather, use historical materials to throw light on or even to destabilize truth regimes of the present, i.e., the object for the Foucauldian approach is not people and ideas of the past, but the forms of rationality and power that all together constitutes a problematic of the present. ${ }^{47}$

On the one hand, in both the philosophical and the historical-hermeneutical approach the following way of explaining the relation between ideas and individuals is present: "inspired by X...", "influenced by the ideas of Y...", "drawing on Z's theory of child development" etc. then he or she did this and that. This model of explanation establishes a relation between pedagogical theories or ideas and the actions of certain individuals. This way the ideas become attachments to the story of the individual (his or her pedagogical view) - or the reverse, the story of the individual become an attachment to the analysis of the idea - and "the taking" of this or that theory is described within an interactionistic frame as either a deliberate choice ("he found them inspiring") or a more subtle influence ("he was inspired by"). These choices or influences are further related to the historical context often described as the time.

On the other hand, whereas the philosophical and historical approaches tell stories that ascribes the motor of history to the dialectic between individuals, ideas and context, the empty ontology of the Foucauldian approach leads to an abandonment of the study of both individuals, their motives and drives and the historical context as an overarching and all-embracing period of time in which these unfold. The Fou-

47 Hultqvist and Petersson (1995), 23. 
cauldian studies directly refuse the search for causes and so they never ask "why"certain ideas arise, disappear or change, are imported/exported, etc. - but restrain their research questions to "how" - certain ideas emerge, combine and connect in old and/or new ways thus (de)forming definite power relations. As a consequence, in these studies, history has no motor and transformations "just" happen. On the other hand, through their epistemological attentiveness, Foucauldian studies have sharpened the discussions of the historical nature of historical concepts and educational ideas. However, when stating an empty ontology where everything is discourse, the systematic study of societal structures constituted by agents and institutions is left unnoticed. Thus, what is gained in descriptive value is lost in explanatory power: history has no motor of change, at least not "external" ones, transformations "just" happen.

The main difference between the philosophical approach and the historical in relation to the driving forces of history seem to be the degree of detail of the context and with whom the ideas are sought: where the philosophers search among the great thinkers (the "classics" such as Plato and Aristotle, the "moderns" such as Kant and Rousseau, and the "contemporaries" such as Dewey and Piaget) and their canonized theories, the historians most of all search among the professionals (architects, doctors, bureaucrats, (preschool) teachers, psychologists, etc.) and their concrete manifestations of ideas in everyday life. This has the consequence of directing the explanations of the emergence of ideas either in the personality of the thinker or in the zeitgeist or the period of the professional. This difference also sets the philosophical apart from the historical and the Foucauldian approach in relation to the sources used as empirical materials. Studies within the philosophical approach tend to use the easily accessible theories mainly published in books; studies within the Foucauldian approach tend to supplement these theories with state papers (laws, guides/ manuals, commission reports, etc.); and studies within the historical approach tend to supplement all of this with institutional and personal archives, professional journals, memorials, etc.

All in all, it seems that while the philosophical and the Foucauldian approach deploy a keen eye for internal dimensions (logic and power respectively), and while the historical-hermeneutical approach meticulously travel through detailed archives to "uncover" stories of the interweaving of external contexts, biographical characters and courses of events, they all seem to discard the systematic study of social structures in which ideas and theories are conceived.

\section{Categories, ideas and knowledge as social forms - educational theory expla- ined by sociological terms of social space and symbolic power}

The discussion above suggests that the three approaches share a common - by lack of interest or by direct refusal - "blind spot", i.e., a consistent theoretical conception of the agent as a social being and the relation between structure and agent, breaking away from structuralism and other holistic approaches by "shifting [his] analytic focus 'from structure to strategy', from mechanical mental algebra of cultural rules to the fluid symbolic gymnastics of socialised bodies." ${ }^{48}$ These "fluids" can be empirically engaged within a social space and social history approach in order to understand

48 Loïc Wacquant, "Following Pierre Bourdieu into the Field," Ethnography 5, no. 4 (2004), 389. 
the social structures and processes that produce and reproduce educational theory.

Within the Danish milieu of educational science, the sociology of Pierre Bourdieu has had a significant influence. However, in the study of educational ideas it has not had a great impact as the Bourdieusian dogma that practice has its own logic seems to have pushed the study of educational theories aside. However, it seems perfectly in line with a Bourdieusian perspective to study how educational theories of all sorts manifests themselves in a pedagogical field; how they produce the symbols and categories that educators use when they talk and impose meaning on their practice and how they function as a text corpus legitimizing professional autonomy and monopoly as well as esprit de corps. ${ }^{49}$

To further investigate this line of thought, the strand of what has become labeled as the new sociology of knowledge $e^{50}$ is helpful. These broadly collected diverse studies unite in taking as a point of departure the traditions originating in works of Emile Durkheim and Karl Mannheim respectively. ${ }^{51}$ Drawing on the traditions and inspirations from the wide-ranging perimeter of sociology of knowledge at one end, and sociology of science and intellectuals at the other, and outlining a new direction apart from "humanist", "contextualist", and "poststructuralist" approaches, this new sociology of ideas "seek to uncover the relatively autonomous social logics and dynamics, the underlying mechanisms and processes that shape and structure life in the various social settings intellectual inhabit". ${ }^{2}$

Holding Randall Collins' great work on the sociology of philosophies as a key-reference, Gross, e.g., in his study of the philosophy of Richard Rorty, maps out the networks and microcosms within the colleges (Hutchins and Wellesley) and universities (Princeton and Yale) that constituted the social settings in which Rorty's biographical properties (such as influence of the cultural-intellectual milieu of his New York-bohemian parents) unfolded and in which his ideas and theories were conceived and received, thus producing "pragmatism" as a distinct philosophy. In a similar vein Michèle Lamont followed the different legitimation processes that made Derrida a "dominant French philosopher" in France and the US, highlighting the difference between the fit between the work and the respective intellectual markets (with professional institutions and journals playing a central role in the US while the cultural media and larger intellectual public were more important in France). ${ }^{53}$ Both Lamont and Gross draw on the sociology of Pierre Bourdieu but stress the need for descriptions and explanations closer to the individual, which in some ways resemble

49 Peter $\varnothing$. Andersen, Podagogens praksis (København: Munksgaard/Rosinante, 1995); Ulf Brinkkjær and Morten Nørholm, "Praktisk teori på ethjulet cykel," Dansk poedagogisk Tidsskrift 2 (2002), 8291 also outline this thought.

50 Charles Camic and Neil Gross, "The New Sociology of Ideas," in The Blackwell Companion to Socio$\log y$, ed. Judith Blau (Malden: Blackwell, 2001).

51 Charles Camic, "Sociology of Knowledge," in International Encyclopedia of the Social and Behavioral Sciences (Amsterdam: Elsevier, 2001), 8 144; Camic and Gross (2001), 238; Charles Camic, Neil Gross and Michèle Lamont, "The Study of Social Knowledge Making," in Social Knowledge in the Making, eds. Charles Camic, Neil Gross and Michèle Lamont (Chicago \& London: University of Chicago Press, 2011), 1-40.

52 Neil Gross, Richard Rorty: The Making of an American Philosopher (Chicago: University of Chicago Press, 2008), 11.

53 Michèle Lamont, "How To Become a Dominant French Philosopher: The Case of Jacques Derrida," American Journal of Sociology 93 (1987), 584-622. 
the work of the historian as we have depicted it, more than the work of a sociologist. ${ }^{54}$ Gross, etcetera, write that in a Bourdieusian analysis "the human being as a whole becomes a vanishing point" and that instead of representing "an independent level of reality governed by its own laws" the body, like the human being more generally, "ends up figuring as a tabula rasa ... a blank slate on which the dispositions of the habitus are written" 55 . To remedy this Gross coins the theory of the intellectual self-concept that holds that "intellectuals are bearers of identities whose contents often have little to do with their field positions but which may nevertheless influence the views they come to hold" 56 .

In another kind of continuation of Bourdieu, encouragement can be found in Loïc Wacquant's works. He has followed the links in a long chain of institutions, agents and ground works (such as counseling notes, committee reports, white papers, delegations, debates, expert symposiums, scientific and popular scientific works, etc.) in order to understand the import-export mechanisms of the international spread of American crime policies and their manifestation in Europe especially. ${ }^{57}$ This perspective have been widened in "On the Cunning of Imperialist Reason", where Bourdieu and Wacquant traces the social conditions and the cultural channels of international ideas and conceptualization of the social world through a focus on the circulation of intellectual texts and their powerful support in international organizations and public policy think tanks. ${ }^{58}$

The above-mentioned examples of a social space and history approach are different which suggests that the study of ideas and theories in relation to the social structures (or "society" or "social space") is a complex matter. Consequently, we want to show and discuss which elements and kinds of complexity are at play, in which way, when incorporating social structure, society or social space in the study of educational ideas or theories. Doing this, we draw on the new sociology of knowledge and ideas and we sharpen up the Bourdieusian grounding which stimulated this strand of sociology.

Firstly, the status of an idea or a theory changes systematically compared to the first three approaches. The Bourdieusian notion of field (and space), which is a thorough relational mode of thinking, clarifies this change. A field can be defined as a system of relations between positions occupied by agents and institutions that struggle over something that is common for them all. To be able to construct systems of relations between positions, one must first obtain basic knowledge of the field like an anthropologist getting to know the ("foreign" or "strange") context, and like the historian who immerses herself in historical sources. So, basic anthropological or anthropological-historical work is a prerequisite to do social space and social history work too. A field is a relatively autonomous world with its own logic, demands

54 This stance juxtaposes Bourdieu's basic epistemological suggestion that the object must be constructed relationally. For Bourdieu, then, the field is the object of scientific investigation whereas Gross takes the author and his idea in itself though within a historical and social context as object of investigation.

55 Gross (2008), 247.

56 Ibid., 255.

57 Loïc Wacquant, Prisons of Poverty (Minnesota: University of Minnesota Press, 2009 [org. 1999]).

58 Pierre Bourdieu and Loïc Wacquant, "On the Cunning of Imperialist Reason," Theory, Culture and Society 16, no. 1 (1999), 41-58. 
of entry, standards of success or failure, rewards and benefits, etc. Thus, Bourdieu invites us to understand ideas and pedagogical theories not in terms of their intrinsic logic, coherency or deeper meaning, but in terms of their relation to other ideas and theories that all together form a more or less autonomous space of stances or position-takings. In this way, the approach echoes Foucault, although a Foucauldian approach would not include a focus on a relational positioning of ideas related to agents and institutions, because the approach lacks a sociological group-making perspective.

In a Foucauldian approach there is no sociohistorical concept of the social, society or a social space adding power, forming or structuring knowledge or ideas. ${ }^{59}$ When using the science of sociology, there is. Thus, secondly the question is how the sociohistorical and structural powers are present - as external factors to ideas and knowledge and/or as embedded in them, i.e. as internal to ideas and knowledge. Incorporating a concept of "society/the social", it is acknowledged that "society/the social" cannot be reduced to aggregates of social relations or interactions between individuals. There is more to "society" than the gathering of individuals. "Society" is a complex collective phenomenon, and social relations between individuals cannot generate this kind of complexity. ${ }^{60}$ Therefore, if we want to know about the history of ideas relating to societal complexity, "society" has to be included in the approach. Now, the question is whether to define "society" as external sociocultural factors to ideas, consequently defining ideas as separate internal content - or to say that sociocultural factors are both internal and external to the content of ideas. ${ }^{61}$ Following Bourdieu, and the Norwegian social anthropologist Fredrik Barth as well, "society" as objectified external factors should not be separated absolutely from the social processes in a field, i.e. the production of an idea in relation to other ideas. "Society" is not only a phenomenon of abstraction separated from social processes and specific production in a field. "Society" is also graspable as and part of social processes understood as societal practice. ${ }^{62}$ Thus, the challenge would be constructing educational theory (ideas or knowledge) theoretically, using Bourdieu's concepts of field, categorisation and capital as prerequisites for analysis. This strategy of theoretical construction is able to meet a double track of "society" as both objectified and "external", and as fused into a field's special issues or "internal" affairs through agents and their compatible and/or opposing stances on the issue in question. These theoretical constructions thus exclude reading social science and social history as "dehumanising" normative economism connected to Marxism, the philosophical tradition Nordenbo among others read as the intellectual force behind the emergence of social theory in educational science in the 1950s.

The distinction between knowledge and social knowledge on the one hand, and

59 The foucauldian notion of episteme, although embracing discursive relations and formations in a broad sense, does not entail a sociological concept of society; it does not perceive of statements, symbols or epistemological practices as anchored in and energized by agents or institutions and their social positioning, cf. Foucault (2002), 211-2.

60 Emile Durkheim, Den sociologiske metodes regler (København: Hans Reitzels forlag, 2000 [org. 1895]); Fredrik Barth, Manifestasjon of prosess (Oslo: Universitetsforlaget, 1992).

61 Camic (2001), 8146

62 Barth (1992); Pierre Bourdieu, “Kapitalens former," Agora: Journal for Metafysisk Spekulation 1-2 (2006 [org. 1983]): 5-26. 
discussions on whether scientific knowledge areas could be studied as sociological phenomena in line with non-scientific knowledge areas on the other hand, is $\mathrm{cm}$ parable with the internal-external discussion. When Camic and Gross write about rational, scientific areas of thought as related to sociohistorical conditions, this is an example of an internalistic view of a special form of production of ideas, i.e. scientific ideas. ${ }^{63}$ When Bourdieu wants to study the ignored historical conditions of knowledge production processes and emergences of the French intellectual field, it is another matter. For Bourdieu, "it is not possible, even in the case of the scientific field, to treat the cultural order (the episteme) as totally independent of the agents and institutions which actualize it and bring it into existence, and to ignore the socio-logical connections which accompany or underwrite logical sequences" ${ }^{64}$. For Bourdieu it is crucial to relate the space of position-takings to the space of positions, and further to relate these spaces to the dispositions of the agents that occupy the positions and take the stances, and to the overall social world in which the field is situated. This does not mean, however, that Bourdieu reduces the cultural works to simple reflections of an external social world. External factors - economic crises, technical transformations, political revolutions, etc. - exercise efficacy in the field only through the intermediation of the specific logic of the field.

Distinguishing between knowledge and social knowledge might point to stances regarding the internal-external issue too. Using the concept of knowledge seems to suggest internal, rational, separate and individualistic (scientific) knowledge and ideas, not stressing the practice of knowledge and the social making of knowledge. However, the concept "social knowledge" does. This concept stresses social knowledge practices as patterned activities, focussing on the participation in producing, evaluating and using what empirically counts as social knowledge inside and outside the academy. ${ }^{65}$

Thirdly, using the science of sociology to study the emergence and transformation of educational ideas and theory, the understanding of history and its driving forces is different from the first three approaches. The theoretical construction of ideas as social forms and structures should be combined with the in-principle inexhaustible amounts of sources about the emergence and transformation of ideas and moreover history at large. ${ }^{66}$ This means that in order to grasp emergences and transformations one needs to be able to compare sets of historical relations of educational ideas as categories and capital (position takings) - related to social space (positions) and the field of power at the given point in time. Doing this, one would be able to write a relational structural history based on ideas and knowledge as practices; as ideas and knowledge in the making. This means that the ideas to be studied must be placed in a structure of categorised and classified agents and institutions in order to make sociological sense - even when it comes to the history of ideas. The object of study

63 Camic and Gross (2001).

64 Pierre Bourdieu, The Rules of Art: Genesis and Structure of the Literary Field (Stanford: Stanford University Press, 1996), 198.

65 Camic, Gross and Lamont (2011), 4, 7.

66 Pierre Bourdieu, The State Nobility: Elite Schools in the Field of Power (Cambridge: Polity Press, 1996), 325. 
still needs to be constructed. ${ }^{67}$ In this is embedded a specification of history's driving forces. For example, Bourdieu states, "there is action, history, and preservation or transformation of structures only because there are agents. But these agents are only effective and efficient because they are [...] endowed with a set of dispositions that imply both their propensity and their ability to enter into and play the game". ${ }^{68}$ The objectified history only becomes active historical action if it is taken in charge by agents, that have a history that predisposes them to do so, "who, by virtue of their previous investments are inclined to take an interest in its functioning, and endowed with the appropriate attributes to make it function". ${ }^{69}$ Ideas are thus studied through the social agents and institutions that produce them and through whom and which they circulate. This implies that - contrary to the Foucauldian studies that refuses to explain ideas with anything other than ideas (since everything is ideas) and therefore remains satisfied with the mere description of historical breaks between ideas - the sociological approach gains explanatory power from the social, that is, from the concrete empirical study of the historical confrontations between positions and dispositions, between the structure of the market or the space of possibles and the strategies of agents. ${ }^{70}$ Again, the concept of field sums up the sort of complexity that needs to be illuminated: "The notion of field allows us to bypass the opposition between internal reading and external analysis without losing any of the benefits and exigencies of these two approaches [...]."71

\section{Educational theory as social forms - concluding remarks on the social ma- king of educational theory}

Concluding the article, we reshape what has been displayed in the previous section compared to the first three approaches. In order to understand a pedagogical stance in the form of an idea or a theory one must know the universe of stances offered by the field at a given moment, and the external powers and demands that force themselves upon the field. As Bourdieu unmistakably puts it: "[A]dopting a stance, a prise de position, is as the phrase clearly suggests, an act which has meaning only relationally, in and through difference, the distinctive deviation." ${ }^{2}$ This invites us to focus not on the intrinsic but on the distinctive value of the pedagogical idea or theory, i.e. in relation to other ideas or theories, which implies the construction of "the complete system of relations which informs it"73.

$\overline{67 \text { Noiriel (1994), } 554 .}$

68 Bourdieu (1996a), 38.

69 Pierre Bourdieu, "Men and Machines," in Advances in Social Theory and Methodology: Toward an Integration of Micro- and Macro-Sociologies, eds. Karin Knorr-Cetina and Aaron V. Cicourel (Boston: Routledge \& Kegan Paul, 1981), 306.

70 Contrary to Gross' reading of Bourdieu, we would highlight that the struggle capital is not the only motor of change in Bourdieu's work. Since social agents are emotionally invested in the world, the search for recognition and dignity is one of the driving motors of social conduct. Pierre Bourdieu, Pascalian Meditations (Stanford: Stanford University Press, 2000).

71 Bourdieu (1996a), 205. Some historians might say that the writing of history is a matter of what it is possible to gain knowledge about due to the scarce and scattered nature of sources and for that reason theoretical concepts such as field may pose unachievable demands. However, this goes for all research processes and is not particularly a challenge to the historian.

72 Pierre Bourdieu, Language and Symbolic Power (Cambridge: Harvard University Press, 1991), 177.

73 Pierre Bourdieu, The Political Ontology of Martin Heidegger (Cambridge: Polity Press, 1991), 6. 
Furthermore, it invites us to study not the ideas of ("great" or "prominent") individuals, but ideas as social forms, and agents as social beings, in terms of their classified social and symbolic resources and activities (capital). The practice and structure of the social making of educational theory needs to be classified on the basis of a whole lot of sources and according to a multidimensional theory of social space and group-making that occurs through symbolic classification struggles. The individuals participating in this spectacle of making theory are individuals with a specific taste for pedagogy, who are using particular categories, and involving themselves in significant activities through which they and their theory gain legitimacy.

Such a sociological approach means that the emergence and transformation of educational theory is not to be reduced to formal levels of law, economy, political or educational philosophy. Instead, the practice of theory is considered to be complex in ways that the logic of formality and normative theory cannot explain. Thus, this article has confronted a dominant line in Western political philosophy. Others have pointed out that the lack of ambiguity in the ease of formality stems from a dominant line of thought in Western political philosophy, i.e. the juridical-philosophical model of the state or the sovereign. ${ }^{74}$ The basic assumption in this model is that law, contracts, or other kinds of formal normativity are governing practice downwards in one dimension. Using a multidimensional theory of the social space prevents us from moving down that line of thought.

We have argued that the three first-mentioned approaches in different ways ignore or do not use a theoretically reflected and empirically based notion of the social conditions that play a part in the production and unfolding of educational ideas and theories that can be remedied by looking in the direction of the so-called new sociology of knowledge. Against the empiricism of the philosophical and historical approaches, this position offers an applied rationalism that invokes clearly defined and elaborated concepts in order to guide and structure the empirical study in a systematic way. More so, against the mere descriptive and destabilizing ambitions of the Foucauldian approach, the sociological approach draws on explanatory models that avoid reference to both "the greatness of the consecrated philosopher-thinker" and "the Zeitgeist", "the spirit of the time" and the vague notion of "context". We have argued that the sociology of Bourdieu provides a useful toolbox for the study of the social production of educational ideas and theories, with the caveat that this is yet to be put to work empirically.

\section{Acknowledgements}

This article has benefitted from stimulating comments and suggestions from a number of people. We would like to thank the participants in the seminar The social making of educational theory held at University of Copenhagen, Department of Education in November 2013: Tone Saugstad, Bolette Moldenhawer, Marta Padovan-Özdemir, Eva Bertelsen, Rasmus Præstmann Hansen, and Gerd Christensen. We also benefitted from encouraging discussions with the participants in the session Writing contemporary history of education - challenges and methods in Europe-

74 Mekonnen Tesfahuney and Magnus Dahlstedt, "Lägrets politik: Undantagstillstånd, övervakningsansamlingar och migration," in Viljan att styra: Individ, samhälle och välfärdens styringspraktiker, eds. Sofia Lövgren and Kerstin Johansson (Lund: Studentlitteratur, 2007), 145; Foucault (2002), 266. 
an Social Science History Conference in Vienna April 2014, especially Iben Vyff, Lisa Rosén Rasmussen, Johan Prytz, Karin Zetterqvist, and Bengt Sandin. Finally we would like to thank Christian Ydesen for useful comments on an earlier draft. 


\section{References}

Andersen, Peter Ø. Poedagogens praksis. København: Munksgaard/Rosinante, 1995.

Andersen, Peter Ø. "Pædagogik og pædagogiske teorier i Danmark fra 1960." In Klassisk og moderne pcedagogisk teori, edited by Peter $\varnothing$. Andersen, Tomas Ellegaard and Lars Jakob Muschinsky, 54-96. København: Hans Reitzels Forlag, 2007.

Barth, Fredrik. Manifestasjon og prosess. Oslo: Universitetsforlaget, 1992.

Bendixen, Carsten. Psykologiske teorier om intelligens og folkeskolens elevdifferentiering: En analyse af transformationen af psykologiske teorier om intelligens som baggrund for skole-psykologiske og poedagogiske afgørelser vedrørende elevdifferentiering $i$ det 20. århundredes folkeskole. Roskilde: Roskilde Universitetscenter, 2006.

Bourdieu, Pierre. "Men and Machines." In Advances in Social Theory and Methodology: Toward an Integration of Micro- and Macro-Sociologies, edited by Karin Knorr-Cetina and Aaron V. Cicourel. Boston: Routledge \& Kegan Paul, 1981.

Bourdieu, Pierre. Language and Symbolic Power. Cambridge, Massachusetts: Harvard University Press, 1991.

Bourdieu, Pierre. The Political Ontology of Martin Heidegger. Cambridge: Polity Press, 1991.

Bourdieu, Pierre. The Rules of Art: Genesis and Structure of the Literary Field. Stanford: Stanford University Press, 1996a.

Bourdieu, Pierre. State Nobility: Elite Schools in the Field of Power. Cambridge: Polity Press, 1996b.

Bourdieu, Pierre. Pascalian Meditations. Stanford: Stanford University Press, 2000.

Bourdieu, Pierre. "Kapitalens former." Agora: Journal for Metafysisk Spekulasjon 1-2 (2006 [1983]), 5-26.

Bourdieu, Pierre and Loïc Wacquant. "On the Cunning of Imperialist Reason." Theory, Culture and Society 16, no. 1 (1999), 41-58.

Brinkkjær, Ulf and Morten Nørholm. "Praktisk teori på ethjulet cykel." Dansk poedagogisk Tidsskrift 2 (2002), 82-91.

Burchell, Graham, Colin Gordon and Peter Miller. The Foucault Effect: Studies in governmentality. Chicago: The University of Chicago Press, 1991.

Callewaert, Staf. "Hvordan skal man skrive den danske pædagogiks historie?" Tidsskrift for Nordisk forening for poedagogisk forskning 3-4 (1984), 67-79.

Camic, Charles. "Sociology of Knowledge." In International Encyclopedia of the Social \& Behavioral Sciences, 8 143-48. Amsterdam: Elsevier, 2001.

Camic, Charles and Neil Gross. "The New Sociology of Ideas." In The Blackwell Companion to Sociology, edited by Judith Blau, 236-49. Malden, MA: Blackwell, 2001.

Camic, Charles, Neil Gross and Michèle Lamont. "The Study of Social Knowledge Making." In Social Knowledge in the Making, edited by Charles Camic, Neil Gross, and Michèle Lamont, 1-40. Chicago and London: The University of Chicago Press, 2011.

Carr, Edward H. What is History? London: Penguin Books, 1990 [org. 1961].

Charle, Christophe. "Contemporary French Social History: Crisis or Hidden Renewal?" Journal of Social History 37, no. 1 (2003), 57-68.

Christensen, Gerd. Individ og disciplinering: Det poedagogiske subjekts historie. Frederiksberg: Samfundslitteratur, 2008. 
Cunningham, Hugh. Children and Childhood in Western Society since 1500. Harlow \& New York: Pearson Longman, 2005.

de Coninck-Smith, Ning. "Legeteorier, leg og legepladser." Tidsskrift for børne- og ungdomskultur 30 (1993), 19-32.

de Coninck-Smith, Ning. For barnets skyld: Byen, skolen og barndommen, 18801914. København: Gyldendal, 2000.

de Coninck-Smith, Ning. "Det demokratiske børneopdragelsesprogram: Anne Marie Nørvig om børn, forældre og familie i USA og Danmark i 1930-1955." In Samfundets børn, edited by Mads Hermansen and Arne Poulsen, 13-34. Aarhus: Klim, 2002.

de Coninck-Smith, Ning. "The Panopticon of Childhood: Harold E. Jones Child Study Center, Berkeley, California, 1946-1960." Paedagogica Historica 41, no. 4-5 (2005), 495-506.

de Coninck-Smith, Ning. "Danish and British Architects at Work: A Micro-Study of Architectural Encounters After the Second World War." History of Education 39, no. 6 (2010), 713-30.

Durkheim, Emile. Den sociologiske metodes regler. København: Hans Reitzels Forlag, 2000 [org. 1895].

Fass, Paula S. "Cultural History/Social History: Some Reflections on a Continuing Dialogue." Journal of Social History 37, no. 1 [Special issue], (2003), 39-46.

Foucault, Michel. "Questions of Method." In Power: Essential Works of Foucault 1954-1984, Vol. 3, edited by James D. Faubion. New York: The New Press, 2000 [org. 1980].

Foucault, Michel. The Archaeology of Knowledge. London: Routledge, 2002 [org. 1969].

Foucault, Michel. "Nietzsche, Genealogy, History." In The Foucault Reader, edited by Paul Rabinow. New York: Pantheon Books, 1984.

Gross, Neil. Richard Rorty: The Making of an American Philosopher. Chicago: The University of Chicago Press, 2008.

Grue-Sørensen, Knud. Opdragelsens historie I-III. København: Gyldendals Pædagogiske Bibliotek, 1959.

Hamre, Bjørn. Potentialitet og optimering: Problemforståelser og optimering i skolen. Aarhus: DPU, Aarhus Universitet, 2012.

Hofstetter, Rita and Bernhard Schneuwly. "Institutionalisation of Educational Sciences and the Dynamics of Their Development." European Educational Research Journal 1, no. 1 (2002), 3-26.

Hultqvist, Kenneth. Förskolebarnet: En konstruktion för gemenskapen och den individuella frigörelsen. Stockholm: Symposion Bokförlag, 1990.

Hultqvist, Kenneth. "Changing Rationale for Governing the Child: A Historical Perspective on the Emergence of the Psychological Child in the Context of Preschool - Notes on a Study in Progress." Childhood 4, no. 4 (1997), 405-24.

Hultqvist, Kenneth and Kenneth Petersson. "Nutidshistoria: Några inledande utgångspunkter.” In Foucault: Namnet på en modern vetenskaplig och filosofisk problematik, edited by Kenneth Hultqvist and Kenneth Petersson, 16-37. Stockholm: HLS Förlag, 1995.

Hunt, Lynn. The New Cultural History. Berkeley, Los Angeles \& London: University of California Press, 1989. 
Iggers, Georg G. Historiography in the Twentieth Century: From Scientific Objectivity to the Postmodern Challenge. Middletown: Wesleyan University Press, 2005 [org. 1997].

Koselleck, Reinhart. The Practice of Conceptual History. Stanford: Stanford University Press, 2002.

Krejsler, John B. "Quality Reform and 'the Learning Pre-School Child' in the Making: Potential Implications for Danish Pre-School Teachers." Nordic Studies in Education 32, no. 2 (2012), 98-113.

Lamont, Michèle. "How to Become a Dominant French Philosopher: The Case of Jacques Derrida." American Journal of Sociology 93 (1987), 584-622.

Larsen, Jesper Eckhardt. J.N. Madvigs dannelsestanker: En kritisk humanist i den danske romantik. København: Museum Tusculanum, 2002.

Lützen, Karin. Byen tommes: Kernefamilie, sociale reformer og velgørenhed i 1800 tallets København. København: Hans Reitzles Forlag, 1998.

Lützen, Karin. "Kaspar Villadsen: Det sociale arbejdes genealogi. Om kampen for at gøre fattige og udstødte til frie mennesker," Dansk Sociologi 3 (2005), 107-9.

Løkke, Anne. Døden i barndommen: Spcedbørnsdødelighed og moderniseringsprocesser i Danmark 1880 til 1920. København: Gyldendal, 1998.

Nordenbo, Sven Erik. "Uddannelsesforskning - pædagogik, en humanistisk disciplin", Nyt om uddannelsesforskning 1, no. 3 (1981), 3-6.

Nordenbo, Sven Erik. Bidrag til den danske peedagogiks historie. København: Museum Tusculanums Forlag, 1984.

Plum, Maja. "The Emergence of the Analytical Method in Early Childhood Education." The International Journal of Qualitative Studies in Education 25, no. 5 (2012), 645-63.

Popkewitz, Thomas. "Dewey, Vygotsky, and the Social Administration of the Individual: Constructivist Pedagogy as Systems of Ideas in Historical Spaces." American Educational Research Journal 35, no. 4 (1998a), 535-70.

Popkewitz, Thomas. Struggling for the Soul. The Politics of Schooling and the Construction of the Teacher. New York: Teachers College Press, Colombia University, 1998b.

Popkewitz, Thomas and Marianne Bloch. "Administering Freedom: A History of the Present - Rescuing the Parent to Rescue the Child for Society." In Governing the Child in the New Millenium, edited by Kenneth Hultqvist and Gunilla Dahlberg, 85-118. London/New York: Routledge Falmer, 2001.

Prytz, Johan. Speaking of Geometry: A Study of Geometry Textbooks and Literature on Geometry Instruction for Elementary and Lower Secondary Levels in Sweden, 1905-1962, With a Special Focus on Professional Debates. Uppsala: Uppsala University, 2007.

Rømer, Thomas Aastrup. At loere noget $i$ en verden uden geloender: En kritisk diskussion af nyere loeringsteori. København: Danmarks Pædagogiske Universitets Forlag, 2005.

Rømer, Thomas Aastrup. Uddannelse i spoending: Åbenhjertighedens, påmindelsens og tilsynekomstens predagogik. Århus: Klim, 2010.

Simonsen, Dorthe Gert. Tegnets tid. København: Museum Tusculanums Forlag, 2003. 
Tesfahuney, Mekonnen and Magnus Dahlstedt. "Lägrets politik: Undantagstillstånd, övervakningsansamlingar och migration." In Viljan att styra: Individ, samhälle och välfärdens styrningspraktiker, edited by Sophia Lövgren and Kerstin Johansson. Lund: Studentlitteratur, 2007.

Villadsen, Kaspar. Det sociale arbejdes genealogi: Om kampen for at gøre fattige og udstødte til frie mennesker. København: Hans Reitzels Forlag, 2004.

von Oettingen, Alexander. Pcedagogisk filosofi som reflekteret omgang med predagogiske antinomier: Perspektivering af K. Grue-Sørensens filosofiske pæedagogik. Århus: Klim, 2006.

Wacquant, Loïc. "Following Pierre Bourdieu into the field." Ethnography 5, no. 4 (2004), 387-414.

Wacquant, Loïc. Prisons of Poverty. Minnesota: University of Minnesota Press, 2009 [org. 1999].

Winther-Jensen, Thyge. Undervisning og menneskesyn hos Platon, Comenius, Rousseau og Dewey. København: Akademisk Forlag, 2004.

Ydesen, Christian. The Rise of High-Stakes Educational Testing in Denmark (19201970). Frankfurt: Peter Lang, 2011. 